\title{
Göç Olgusunun Çok Boyutlu Etkileri ve Türkiye'ye Yansımaları
}

\author{
Ayşegül GÜLER ${ }^{1}$
}

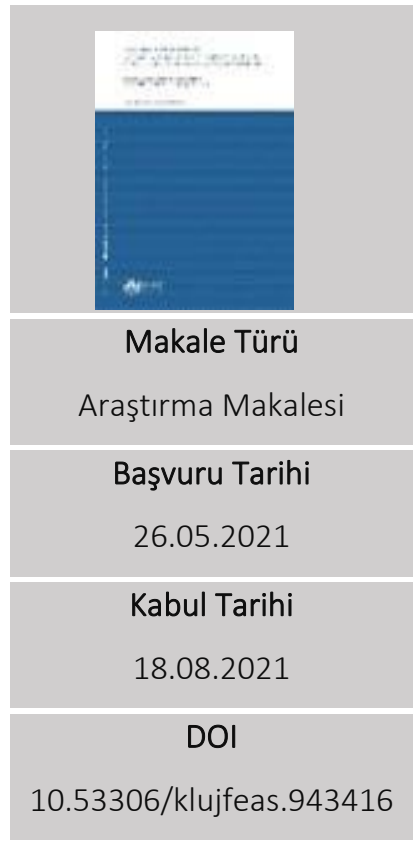

\begin{abstract}
Öz
Göç olgusu, göç veren ülkeleri ilgilendirdiği kadar göç alan ve transit ülkeleri de ilgilendirmektedir. Uluslararası Göç Örgütünün açıkladığı 2020 yılı raporunda 272 milyon uluslararası göçmen vardır ve bu dünya nüfusunun \% 3.5'idir. Günümüzde göçler, hayat seviyesinin daha yüksek olduğu güvenlik risklerinin minimize edildiği coğrafyalara, diğer bir ifadeyle istikrarsızlıkların yaşandığı ülkelerden Avrupa'ya yönelmektedir. Göçlerin, göç alan bölgelere özellikle Türkiye'ye etkilerini incelemek çalışmanın ana konusunu oluşturmaktadır. Türkiye, Doğu-Batı geçiş güzergâhında bulunan bir ülke olduğundan ekonomik, sosyal ve güvenlik bakımından göç olgusunun değişik türlerini aynı anda yaşamaktadır. Türkiye, ülkeye gelenleri misafir kabul etmekte ve uluslararası hukukta statüleri belirlenen mülteci terimini kullanmamaktadır. Türkiye değişik ülkelerden dört milyondan fazla mülteciyi misafir etmekte barınma, eğitim ve sağlık hizmetlerini kesintisiz karşılamaktadır.Avrupa ise mültecilere karşı seçici davranırken, ihtiyacı olan işgücünü ucuz ve problemsiz karşılamayı tercih etmektedir. Çalışmada göç hareketlerinin ülkelere ciddi ekonomik yük getirdiği ve sürdürülebilir olup olmadığı sorusuna cevap aranırken, göç dalgalarının etkileri, sonuçları ve ne yapılması gerektiği incelenmiştir.
\end{abstract}

Anahtar sözcükler: Göç, Avrupa, Türkiye, sığınmacı, güvenlik

\footnotetext{
1 Dr. Öğr. Üyesi, Karamanoğlu Mehmetbey Üniversitesi, İktisadi ve İdari Bilimler Fakültesi, Siyaset Bilimi ve Uluslararası Ilişkiler Bölümü, aysegulguler@kmu.edu.tr, ORCID: 0000-0002-5014-4825
} 


\title{
Multidimensional Effects of Migration and Its Reflections on Turkey
}

\author{
Ayşegül GÜLER²
}

\begin{abstract}

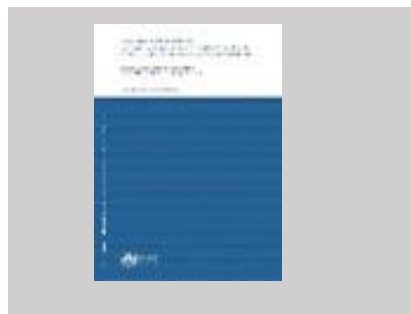

Article Type

Research Article

Application Date

2021-05-26

Acceptance Date

2021-08-18

DOI

10.53306/klujfeas.943416

The phenomenon of migration concerns both emigration and receiving countries. In the 2020 report announced by the International Organization for Migration, there are 272 million international migrants and this is $3.5 \%$ of the world population. Today migrations are directed towards Europe from countries where the life level is higher and where security risks are minimized, that is, from countries where instability is experienced. The main subject of the study is to examine the effects of immigration on regions receiving immigration, especially on Turkey. Since Turkey is a country located on the East-West transition route, it experiences different types of migration phenomenon at the same time in terms of economic, social and security. Turkey accepts those who come to the country as guests and does not use the term refugee whose status is determined in international law. Turkey hosts more than four million refugees from different countries and provides accommodation, education and health services without interruption. While Europe is selective towards refugees, it prefers to meet the labor force it needs cheaply and without any problems. In the study, while seeking an answer to the question of whether migration movements bring serious economic burden to countries and whether they are sustainable, the effects of migration waves, their consequences and what to do is examined.
\end{abstract}

Key words: Migration, Europe, Turkey, refugee, security 


\section{Giriş}

Göç "büyük insan topluluklarının yerlerini, yurtlarını bırakarak daha elverişli yaşam koşulları bulacakları yerlere gitmesi" (Türk Dil Kurumu, 2000, s. 397) olarak tanımlanmakta ve insanlık tarihi içerisinde sürekli gündeme gelmektedir (Goularas ve Sunata, 2015, s. 15). Göçün tabi bir sonucu olarak ortaya çıkan sığınma kavramı da insanlık tarihi kadar eskidir (Barkın, 2014, s. 336). Müslümanların Habeşistan'a sığınması, İspanya Yahudilerinin Osmanlı topraklarına getirilmesi tarihte gösterilebilecek sığınma örnekleridir.

II. Dünya Savaşı döneminde 100 milyon insanın gönüllü veya zoraki nedenlerden yaşadıkları ülkelerden göç ettikleri düşünülmektedir (Ünal, 2014, s. 65). Devam eden süreçte yaşanan Soğuk Savaş nispeten durgun geçse de bu savaşın bitmesi muazzam bir değişim ve belirsizliklerle dolu bir dönemi başlatmıştır. 20. yüzyı sonlarında göç, çeşitli çatışmaların nedeni olarak görülmüş ve yeni güvenlik gündemi tartışmalarında sıklıkla yer almıştır (Castles ve Miller, 1998, s. 1-3). Günümüzde ülke içinde yerinden edilenlerin sayısı 41 milyon gibi rekor bir seviyedeyken uluslararası göç oranı da artmaktadır. İnsanların uluslararası göç etmelerinin başlıca nedeni, çalışma amacıdır. Göçmen işçiler yüksek gelirli ülkelerde yaşamak üzere gitmekte ve uluslararası göçmenlerin büyük çoğunluğunu oluşturmaktadırlar (IOM, 2019). Göçmenler gittikleri her yerde uygun yaşam koşullarıyla karşılaşamamaktadır. Avrupa devletlerinde mülteci konumuna düşmüş insanların en temel insan haklarından yararlanma konusuna kayıtsız kalması, göç hareketlerine çözüm arayışlarını gündeme getirmiştir (Barkın, 2014, s. 334). 1948 İnsan Hakları Evrensel Beyannamesi (IHEB) 14. maddede "herkes zulüm karşısında başka memleketlerden mülteci olarak kabulü talep etmek ve memleketler tarafından mülteci muamelesi görmek hakkına haizdir" (Hâkimler ve Savcılar Kurulu, t.y.) denilerek iltica hakkı temel insan hakkı olarak ifade edilmiştir.

Avrupa kıtasındaki kitlesel mülteci hareketlerine çözüm oluşturulmak amacıyla 1951'de hazırlanıp 1954'de yürürlüğe giren “Mültecilerin Hukuki Statülerine Dair Sözleşme” ilk ciddi teşebbüs olarak bilinmektedir. Cenevre Sözleşmesi ise mültecilerin uluslararası hukukuna dair standartlarını belirleyen, II. Dünya Savaşı yıllarında yerlerinden değişik nedenlerle kopmuş Avrupalı mültecileri konu alan coğrafi ve zaman sınırlaması bulunan ancak Avrupa dışındaki zulümlere duyarsız kalan bir sözleşmedir (Goularas ve Sunata, 2015, s. 18). Sözleşmenin 1. maddesi mülteci tanımını şöyle yapmaktadır: "1 Ocak 1951'den önce meydana gelen olaylar sonucunda ve ırkı, dini, tabiiyeti, belli bir toplumsal gruba mensubiyeti veya siyasi düşünceleri yüzünden zulme uğrayacağından haklı sebeplerle korktuğu için vatandaşı olduğu ülkenin dışında bulunan ve bu ülkenin korumasından yararlanamayan" veya yararlanmak istemeyen şahıslara uygulanmasını öngörmüştür (Mültecilerin Hukuki durumuna Dair Sözleşme, t.y.).

Zaman ve coğrafi sınırlamadan kaynaklanan olumsuzluklar 1967 ek protokolü ile ortadan kaldırılarak göç hareketlerinin dünyanın genel sorunu olarak görülmesine kapı aralanmış, teoride mültecilerin karşılaştığı sorunlar giderilmeye çalışılmıştır (Barkın, 2014, s. 336). Cenevre Sözleşmesi ve 1967 ek protokolüyle çözüm aranan kitlesel göçler tarih boyunca sürekli gündeme gelmişse de son dönemde dünyada eski kriz bölgelerindeki karışıklıklar devam ederken yeni kriz bölgeleri oluşmaktadır (Kartal ve Başçı, 2014, s. 278). Bu nedenle 
çalışmada göç hareketlerinin etkileri ele alınırken, konuya özellikle göç alan ülkeler açısından bakılmış ve ülkelerin uygulamadaki farklılıkları değerlendirilmiştir. Çalışmada genel anlamda küresel, özelde ise bölgemizde yaşanan düzensiz göç hareketleriyle ortaya çıkan veriler karşılaştırmalı içerik analiziyle incelenmiştir.

\section{Göç Olgusu ve Etki Alanının Genişlemesi}

Doğu bloğunun dağılmasından sonra göç hareketlerinde farklılaşma ve artış gözlenmiştir. Hareket halindeki daha fazla insan "düzensiz, yasadışı, kaçak" kavramlarıyla adlandırımakta göç kavramı içinde istenmeyen insan olarak nitelenmektedir (Ulukan, 2013, s. 32). Daha iyi hayat umuduyla yapılan göçler yanında zulüm, baskı ve savaştan kaçmak amacıyla yapılan zorunlu göçler genel göç içerisinde önemli bir yer tutmaktadır. Bazı görüşler yaşanan süreci "göç çağı" olarak nitelendirmektedir (Ünal, 2014, s. 66). Nitekim Uluslararası Göç Örgütünün açıkladığı 2020 yılı raporunda 272 milyon uluslararası göçmen vardır ve bu dünya nüfusunun \% 3.5’idir (IOM, 2019).

Dünyanın değişik bölgelerinde olan farklı refah seviyelerinin, medya ve teknolojik imkânların gelişmesiyle bilinir hale gelmesi (Çakır, 2013, s. 106) ve ulaşım imkânlarının artması göç arzusunu körükleyip, hızlandırmıştır. Sonuç olarak da dünya üzerinde ortaya çıkan göçün devasa boyutlara ulaştığı savunulmaktadır. Geçmişten günümüze devam eden ister yasal ister düzensiz olan göç, 21. yüzyılda kontrol edilemez boyutlara ulaşmıştır (Gün, 2006, s. 29).

Ortaya çıkan göçler boyut, nitelik ve kapsam açısından önemli değişiklikler göstermektedir (Ünal, 2014, s. 65). Dünyada yaşanan istikrarsızlıklar doğudan batıya, güneyden kuzeye göç hareketlerini gündeme getirmiştir (Özdal, 2008, s. 98). Balkanlar, Ortadoğu, Kafkaslar, Güneydoğu Asya, Afrika, Uzakdoğu ve Güney Amerika'da ekonomik ve politik nedenlerle ortaya çıkan çatışmalar dünyadaki göç hareketlerinin sürekli artmasına neden olmaktadır. Ancak bazı araştırmacılar dünyada hareket halinde olan insan sayısının 130 milyon seviyesinde olduğunu, bu sayının dünya nüfusu içindeki oranının tarihi süreç içerisinde fazla değişmediğini, olayın politik nedenlerle abartıldığını ileri sürmektedir. Bu sebepten güvenlik temelli yaklaşımlar konuya çözüm oluşturamamakta (Gün, 2006, s. 27-32) sosyolojik, siyasi ve hukuki boyutları ağır basan göç olgusunun yeni bir perspektiften değerlendirilmesi gerekmektedir.

Günümüz göç hareketlerinde eğilim doğu ve güneyden, kuzey ve batı istikametine gelişmeye devam ederken birden çok ülkeyi etkileyen küresel bir nitelik (Çakır, 2013, s. 107) taşımaktadır. Kuzey yarım kürenin gelişmiş olması bu bölgeleri güney ve doğu ülkeleri açısından çekim merkezi haline getirmektedir (Gün, 2006, s. 27). Peki, gerçekten ekonomik nedenlerle ortaya çıkan göç hareketleri Avrupa ve Amerika'ya mı yapılmaktadır yoksa bu görüş oluşturulan algıdan mı kaynaklanmaktadır? Sanayileşmiş Avrupa ülkelerinin göç konusunda seslerini sürekli yükseltmelerine rağmen oluşturulan algının aksine ciddi boyutlarda göç tehdidi altında olmadıkları düşünülmektedir.

Gerçekte güneyden güneye ve doğudan doğuya gerçekleşen göçe göre gelişmiş ülkelere yapılan göçler abartılacak boyutta değildir (Gün, 2006, s. 30). Gelişmekte olan ülkelerden gelişmiş ülkelere yapılan göçten, gelişmekte olan ülkelerden gelişmekte olan ülkelere 
yapılan göç oranı daha fazladır (Karaca ve Saruç, 2014, s. 1). Dünyadaki mülteci hareketlerinin \% 80'i az gelişmiş veya gelişmekte olan ülkelerde yaşanmaktadır (Kara ve Korkut, 2010, s. 155). En çok göç alan yerlerin Amerika Birleşik Devletleri ve Batı Avrupa olduğu düşüncesine karşı savaş, etnik ve dini çalkantılar nedeniyle göçmenlerin \% 50'sinin batıya yönelmediği görülmektedir. Çok sayıda insan kendi ülkesi içerisinde yer değiştirmekte veya bir başka gelişmekte olan ülkeye geçmektedir (Gün, 2006, s. 30).

Gelişmiş ülkelere yönelik göç hareketleri incelendiğinde ise göçün temel nedeni, gelişmiş ülkelerdeki işgücü ihtiyacının uluslararası göç ile karşılanmasıdır. Yaşlanan nüfus sorununun üstesinden gelmek için, birçok Iktisadi İşbirliği ve Gelişme Teşkilatı (OECD) ülkesi göçü, iş̧̧i ihtiyacını telafi etmek için potansiyel bir çözüm olarak görmektedir (Boubtane, Coulibaly ve Rault, 2013, s. 268). Bu ülkeler yatırım yapmadan, yetişmiş ve ucuz işgücü sağlayarak önemli avantaj oluşturmaktadır (Yılmaz, 2014, s. 1694). Çünkü gelişmiş ülkeler aldıkları mültecileri ihtiyaçlarına göre belirlemekte, çaresizliği fırsata dönüştürmek suretiyle ekonomilerine ivme kazandırmayı amaçlamaktadır (Gün, 2006, s. 30). Göçmenlerin en fazla gitmek istedikleri ülkeler arasında Suudi Arabistan, İngiltere, Fransa, Kanada, Almanya ve Güney Afrika gösterilirken, göç etmek isteyenlerin en yoğun bulunduğu ülkeler ise Hindistan, Sudan, Nijerya, Bangladeş ve Çin gözükmektedir. Türkiye ise göç edilmek istenen ülkeler sıralamasında 15. sırada yer almakla (Keleş, 2017) birlikte komşu ülkelerde yaşanan siyasi ve ekonomik istikrarsızlıklardan doğrudan etkilenmektedir. Ayrıca coğrafi konumu nedeniyle az gelişmiş ülkelerden gelişmiş ülkelere geçiş için tercih edilen transit geçiş yolu olmaktadır.

11 Eylül 2001 sonrası ortaya çıkan gelişmeler sonucu ise dünya mülteci ve sığınmacılar açısından daha da güvensiz hale gelmiştir. 11 Eylül sonrası göç alan ülkeler açısından "yabancı korkusu" yaygınlaşmış, farklı amaçlarla seyahat edenler de suçlu gözüyle görülmüş (Ulukan, 2013, s. 44) ve göç giderek artan bir güvenlik sorunu olarak yorumlanmaya başlamıştır (Bigo, 2002, s. 63-80). Mülteci nüfusun büyük kısmının yaşadığı şartların insan güvenliğinin bütün boyutlarını zayıflattığı, ev sahibi ülkelerin direncini ve iç istikrarını derinden etkilediği (Berti, 2015, s. 48) görüşleri artmıştır. Ayrıca değişik sebeplerle göç hareketleri her zaman yaşanmakta olup, yakın gelecekte iklim değişikliği ve kuraklığa bağ|ı olarak bölgeler arasında mülteci akımının artacağı öngörülmektedir (Kartal ve Başçı, 2014, s. 277). Özellikle suya ulaşma imkânı olmayan bölgelerde yaşayan insanlar hayatta kalabilmek için yer değiştirmek zorunda kalacak ve göç edecektir.

\section{Mültecilerin Karşı Karşıya Kaldığı Ekonomik, Kültürel ve Psikolojik Sorunlar}

Sığınmacıların göç etme nedenleri, cinsiyetleri, göç edilen yerin özellikleri farklı olsa da (Gün, 2006, s. 28) gördükleri zulüm ve yakınlarını kaybetmelerinden kaynaklanan psikolojik sorunları birbirine benzemektedir (Ekşi, 2009, s. 69). Göçmenler resmi veya gayri resmi ayrımcılıkla karşılaşmakta (Ulukan, 2013, s. 34) gelişmiş ülkelerin uyguladığı uyum programları sığınmacıların karşı karşıya kaldığı problemlerin çözümünde yetersiz kalabilmektedir (Kartal ve Başçı, 2014, s. 277). Yaşanan sarsıntı çoğu zaman nesiller boyu devam etmektedir. Göçler sosyal, kültürel, ekonomik ve siyasi hayatı ciddi şekilde etkilemekte, radikal kırılmalara yol açmaktadır. Mülteciler yeni şartlara uyumda istekli olsalar dahi göç öncesinde yaşadıkları travmatik olaylar nedeniyle ağır psikolojik sorunların 
etkisinden (Gün, 2006, s. 28) kurtulamadıkları için genç göçmenler arasında intihar vakalarının sıklığı gözlenmektedir (Ekşi, 2009, s. 70-76).

Göçün büyüklüğü ve zamanlaması, sosyal güvenliğin finansal durumunu etkilemektedir (Duleep, 1994, s. 29). Göç etkileri bakımından hem kaynak ülkeyi (göç veren ülkeyi) hem de hedef ülkeyi (göç alan ülkeyi) derinden etkilemektedir. Bazı kaynak ülkeler açısından göç, işsizliği azaltacak ve döviz girdisi sağlayacak bir olgu olarak görülmektedir. Ancak ülkenin ihtiyacı olan yetişmiş ve kalifiye insanların göç etmesi (Yılmaz, 2014, s. 1692-1693) ülke kaynaklarının gelişmiş ülkelerin ihtiyacına yönelik heba edilmesi anlamına gelmektedir. Göç veren bölgelerde başta üretim açısından olmak üzere ciddi sıkıntılar yaşanmaktadır. Göç alan ülkelerde ise uyum sorunlarının giderilmesi ülke politikaları ve toplumun göçmenlere yaklaşımı ile yakından ilgilidir (Gün, 2006, s. 29-32). Örneğin göç alan ülke fırsatlar yanında ciddi tehlikeyi de beraberinde barındırmaktadır. Sığınmacılar, sığındıkları ülkelerde eski statülerinden daha aşağıda yer bulduklarında kendilerine saygıları azalmaktadır. Ayrıca dil farklıığı hem mülteciler hem de göç alan ülkelerin iç yapısı içinde sıkıntılar oluşturmaktadır. İki dile hâkim olan personel ve mülteci sayısı oldukça azdır. Göç edenlerin etik değerleriyle göç alan ülkelerin etik değerleri uyuşmamaktadır. Gittikleri ülkelerde sığınmacıların yerli halk tarafından dışlanması en sık görülen vakalardandır (Ekşi, 2009, s. 70). Göçmenler kültürel ve psikolojik etki yanında coğrafi ve iklim özelliklerinden de doğrudan etkilenmekte yeni bir dil öğrenme ve içine girdiği toplumun kültürüne adaptasyonda güçlükler yaşamaktadır. Dil sorunu hemen her alanda hizmetlerden yararlanılmasına engel oluşturmaktadır (Kömürcü, Özsoy ve Çobanoğlu, 2011, s. 111-128). Ayrıca "dost-düşman olarak" yapılan sınıflandırmada yabancı olarak değerlendirilmekte ve dost gözükmediği için düşman kategorisinde yer verilmektedir. Yani yabancılar potansiyel düşman olarak görülebilmektedir (Ünal, 2014, s. 85). Bu durum bir anlamda ötekileştirme ve insanları birbirinden uzaklaştırmadır. Çünkü insanlar farklı oldukları düşüncesiyle, kendilerinin iyi tarafta karşısındakilerin de kötü tarafta olduğu varsayımıyla hareket ederken, karşılıklı anlayış ve iyi ilişkiler geliştirememektedir.

Göçün ev sahibi ülke ekonomisi üzerindeki etkisi birçok ülkede tartışılmaktadır. Siyasi tartışma üç temel soru etrafında toplanmıştır. İlk olarak göçmenler ev sahibi ülke ekonomisinde nasıl bir performans sergilemektedir? İkincisi, göçmenlerin yerlilerin istihdam olanakları üzerinde nasıl bir etkisi vardır? Son olarak, hangi göç politikası ev sahibi ülkeye en fazla fayda sağlamaktadır? Eğer göçmenler işverenlerin talep ettikleri becerilerden yoksun ve adapte olmayı zor buluyorlarsa, bu durum ev sahibi ülkede var olan ücret farklılıklarını şiddetlendirmektedir (Borjas, 1994, s. 1 667). Çünkü bu yüzden göçmenler sığındıkları ülkelerde sigortasız güvencesiz çalışmaya razı olmaktadırlar (Çakır, 2013, s. 116). Birleşmiş Milletler Mülteciler Yüksek Komiserliği'nin (BMMYK) ödediği aylık yardım ise bulundukları ülkedeki ikamet harcını karşılayamamaktadır (Kömürcü, Özsoy ve Çobanoğlu, 2011, s. 111128).

Göç olgusu insanların hayatını etkilemeye devam etmektedir. Ancak sığınmacılara karşı ön yargı ve korkular giderek artmakta bazı siyasi çevreler ve basın aracılığıyla ötekileştirme gayretleri körüklenmektedir (Ünal, 2014, s. 77). Göç ile ilgili haberler özellikle internet haberciliğinde yüzeysel yer almakta, düzensiz göçün trajik boyutu okuyucuya haberler 
yeterince araştırılmadan servis edildiğinde birçok olumsuz gelişmeye neden olabilmektedir (Çakır, 2013, s. 110-112). Insan kaçakçıları aracılığıyla hedef ülkelere ulaşmaya çalışan göçmenlerin birçoğunun hayatını kaybetmesi medyanın klasik haberleri arasına girmiştir (Ekşi, 2009, s. 70). Bazı güçler değişik bölgelerde ortaya çıkan mülteci hareketlerini, hedef coğrafyalarına yönelik kullanma eğilimindedir. Bölge ülkelerinin nedeni olmadığı iç savaş ve karışıklıklarda uzaktan gelen güçler etkili olabilirken yine bölge ülkelerinin iç dengeleri bozulmakta ve ne zaman sona ereceği bilinmeyen bir süreci yaşamaktadırlar. Kayıklarla yola çıkan mülteciler hayatını kaybetmiş halde kıyılara geri dönmekte, bazı ülkeler mülteci teknelerini geri dönmeye zorlamakta, motorlarına, yiyeceklerine el koymakta ve onları açık denizde ölüme terk etmektedir. Ayrıca bu örneklere göçe katılanların zaman içerisinde ülkeleri ile bağları kopması da eklenebilir.

\section{Gelişmiş Batı Ülkelerinin Göç ve Mülteci Sorununa Yaklaşımı}

Cenevre Sözleşmesi, Avrupa'da yerinden edilmiş göçmenlerin sorunlarını çözmek amacıyla oluşturulmuştur. Dünya savaşlarından sonra yıkılan, harap olan Avrupa, imarı için ihtiyaç duyduğu iş gücünü dışarıdan karşılama yoluna gitmiştir. Misafir iş̧̧ilerin yerleşik olmaya başladığı dönemden itibaren Avrupa'da azınlık problemi gündeme gelmiş, dışlama siyasetine paralel olarak ucuz yabancı işgücü istenmeyen kitle haline gelmiştir. Avrupa'daki yerleşik işgücü, ülkelerine ulaşan ucuz işgücünün kendilerine ekonomik ve sosyal açıdan zarar verdiğini düşünmektedir. Düzensiz göç, işgücü içinde ücretleri düşüren kesim olarak görülerek düşmanca tavırların gelişmesine veya gizlenen duyguların açığa vurulmasına yol açabilmektedir (Ulukan, 2013, s. 41). Yaşam koşulları tahmin edilemeyen şekilde değişen insanlar genelde yeni gelenleri yani göçmenleri güvensizlik nedeni olarak görürler. Birçok gelişmiş ülkedeki göç düşüncesi; yoksul güneyden ve çalkantılı doğudan gelen, işlerini ellerinden alan, konut fiyatlarını yükselten ve sosyal hizmetlere aşırı yüklenen kitlelerdir. Bu yüzden de göçleri yaşam tarzları ve sosyal uyum açısından tehlike olarak görürler (Castles ve Miller, 1998, s. 13).

Uluslararası birçok alanda olduğu gibi göç politikaları da Batı́nın kendi şartlarına göre oluşturduğu ve batı merkezli çözümler öneren bir süreci öngörmektedir. Aslında Avrupa'nın uyguladığı göç politikası işgücü pazarıdır. İhtiyaç duyduğu kadar göçmenleri istihdam eden Batı, kriz dönemlerinde işten ilk önce göçmenleri çıkarmaktadır. 1980'lerden itibaren batılı ülkeler işgücüne ihtiyaçları kalmadığını ilan ederek yasal göç hareketlerini imkânsız hale getirmiş ve yasa dışı göçlere zemin hazırlamıştır (Yılmaz, 2014, s. 1694). Yani göç hareketleri yine yaşanmış ancak bu durum insanların can güvenliği açısından daha tehlikeli hale gelmiştir.

1990'lardan itibaren ortaya çıkan ekonomik kriz ise göç olgusuna yeni bir boyut kazandırmıştır. Avrupa Birliği (AB) ülkelerinde görülen yüksek işsizlik, düşük istihdam göçün kontrol altına alınması için çalışma başlatılmasına yol açmıştır. Batı öncelikle göçü önlemek ve var olan göçmenleri kendi toplumuyla uyumlu hale getirmek için çalışmalara yönelmiştir. $A B^{\prime}$ de ortaya konan istihdam politikaları beklenen neticeyi vermemiş, emeklilerin maaşlarını karşılarken çalışanların sayılarının azalmasını gündeme getirmiştir. Diğer taraftan Avrupa'da azalan ve yaşlanan nüfus olgusunun kalifiye eleman ve ucuz iş gücü ihtiyacını gündeme getirmesiyle, seçici davranan batı toplumları ülkelerine katkısı olacak kişileri mülteci olarak 
kabul etmeye yönelmiştir. Ancak Batı'nın ihtiyaç duyduğu nitelikli veya ucuz iş gücünü üçüncü ülkelerden karşılaması yasa dışı göçü önleme politikasıyla çelişmektedir (Özdal, 2008, s. 90-119).

Avrupa devletlerinin ihtiyacı dışındaki göçmenlere kapıları kapatması düzensiz göçü teşvik etmektedir. Batılılar kendilerinin yapmak istemediği işlerle ilgili iş gücü açığını yasa dışı yollarla gelen göçmenlerle kapatmaktadır. Bu durum yasadışı örgütlere zemin hazırlamaktadır. Ayrıca göç sırasında çok sayıda insanın ölmesine veya kaybolmasına neden olurken (Yılmaz, 2014, s. 1685) insan kaçakçılarının yasadışı yollarda insanları taşımasına zemin hazırlamaktadır.

Göçmenler Avrupa'nın sıkı denetimi karşısında yasadışı örgütlere büyük paralar ödeyip bir çeşit ölüm yolculuğuna çıkmaktadır. AB ülkelerinin göç politikası yasal yollardan girişi denetim altında tutma esasına dayanmakta (Çakır, 2013, s. 117-118) öncelikle göçü durdurmayı amaçlamakta, konunun insani boyutunu göz ardı etmektedir (Kartal ve Başçı, 2014, s. 280). Yani geri kalmışlık, kıtlık, doğal afet ve iç çatışmalarda Avrupa, kendi coğrafyası dışındaki olaylara duyarsız kalmaktadır (Barkın, 2014, s. 337). Amerika Birleşik Devletleri'nde ise ülkenin ekonomik koşullarının diğer ülkelerden gelen vasıfsız işçiler açısından cazip olmasının sadece vasıflı iş̧̧ilere vize verilerek çözümlenebileceği, vasıfsız iş̧̧ilerin göç etmesi engellenebilirse göçmen akış boyutunun büyük ölçüde azalacağı fikri savunulmaktadır (Borjas, 1995, s. 19). Uluslararası göçmen akışı belli bir süre boyunca ülkeye giren ve ülkeden ayrılan göçmenlerin sayısıdır. Bu akışın nitelik ve büyüklüğünü incelemek, olabilecek önemli bir değişiklikle başa çıkabilmek için göçle ilgili politikalar tasarlanmasını sağlamaktadır (UN SC, 2017, s. 10). Ancak yaşanan kargaşalara karşı Birleşmiş Milletlerde yüzlerce plan hazırlanmasına rağmen bazı kesimler göçmen sorunlarına karşı duyarsız kalmayı tercih etmektedir.

Özellikle Avrupa açısından nüfusun etnik, kültürel, dini ve dilsel bileşimini doğrudan değiştirerek toplumsal kimliği ve kültürü tehdit edebildiği için bir noktaya kadar göçün getirdiği kültürel çeşitlilik kabul edilir ancak bir noktadan sonrası sorun haline gelmektedir (Buzan, 1991, s. 447). İşsizliğin nedeni olarak göçmenlerin gösterilmesi ırkçılığı körüklerken (Ulukan, 2013, s. 41) gelişmiş Batı ülkelerinde aşırı sağ partiler göçmen karşıtı kampanyalarla büyüyüp gelişmiştir. Ancak ırkçılık sadece göçmenlere değil aynı zamanda demokratik kurumlara ve sosyal düzene de tehdittir. Uluslararası göç ve toplum üzerindeki etkileri tartışmalarında ırkçıı̆ın nedenleri ve etkileri merkezi rol oynamalıdır (Castles ve Miller, 1998, s. 13-14). Bu yüzden Avrupa kalkınmasının temelinde yer alan çok kültürlülük teoride kalırken, asimilasyon yöntemleri geliştirilmek istenmektedir. Avrupa'da 1930'larda dillendirilen Yahudi düşmanlığının Alman siyasetinin aracı olarak kullanılması gibi göçmenleri kimliklerinden uzaklaştırma siyaseti uygulanmak istenmektedir.

Neticede gelişmiş ülkelerde insan hakları ve demokratik değerlerle güvenlik ve egemenlik arasındaki denge arayışı sağlıklı bir politika oluşmasını engellemekte (Özdal, 2008, s. 97) hukukun üstünlüğü göçmenler açısından göz ardı edilmekte toplumu dil, din, ırk yönünden ayırma yoluna gidilmektedir. Günümüzde Batı Avrupa'da yabancı terimi göçmenleri veya azınlıkları ifade etmek için kullanılmaktadır (Çakır, 2013, s. 113). Insan hakları bazı alanlarda vatandaşların hakları olarak değerlendirilmekte, ülke vatandaşı olmayan yabancılar 
dışlanmaktadır. Yabancıların temel insan haklarından yararlanamaması normal görülebilmektedir (Özdal, 2008, s. 119). Yine ekonomiye katkısı olmayanlara kapıları kapatan Avrupa, mültecilere sağladığı sağlık hizmetlerini de içine alan faaliyetlerini ücretlendirmektedir (Ulukan, 2013, s. 33). Avrupa ülkelerine göre mülteciler birçok nedenle $A B$ vatandaşlarından daha fazla yoksulluk riski taşımakta, kamu hizmetlerinden yararlanamamakta ve istihdamda zorluklar yaşamaktadır (Özdal, 2008, s. 119). Ayrıca Avrupa'yı imar etmek için getirilen göçmenlere yönelik sosyal devlet anlayışı ileri sürülerek çocuklar ailelerinden koparılmakta, koruma altına alınarak devşirilmek istenmektedir. Aile birleştirilmelerine engeller çıkarılmakta, göçmenlerin geldikleri ülkelerle bağlarının koparılmasına yönelik yöntemler geliştirilmektedir. Göçmenlerin anadillerini öğrenmeleri istenmemekte, dini ihtiyaçlarını karşılamak için din adamı getirilmesi yasaklanmaktadır. Göçmenlere geldikleri ülkelerde geleceklerinin olmadığı kabul ettirilmeye çalışılmaktadır. Ancak realiteye bakıldığında gelecekte de Avrupa'nın ucuz işgücü merkezi olmaya devam edeceği görülmektedir (Çakır, 2013, s. 117-118). Özetle Suriye olayları Cenevre'de başlatılan Anayasa Komisyonu çalışmalarıyla çözülmeye çalışılmaktadır. Ancak bölgede yükselen savaş ve mülteci akınının her an yükselme ihtimali gölgesinde yapılan görüşmelerde Avrupa, çözümün önemli bir parçası olmayı isterken Suriye'den kaçan insanlara gözlerini ve sınırlarını kapalı tutabilir mi? (Fargues, 2014, s. 1). Avrupa bu konuyu kendi içinde tutarlı şekilde açıklayabilmelidir. Ayrıca devletler göçü daha yasal, düzenli ve karşılıklı olarak faydalı bir süreç haline getirmek için nasıl çalışılacağını araştırmalıdır (Migration Policy Institue).

\section{Türkiye'nin Göç Politikası ve Topluma Yansımaları}

Türkiye tarihi süreç içinde göçlere yabancı olmamakla birlikte 21. yüzyıl başından itibaren Doğu-Batı ve Güney-Kuzey yönünde yapılan göçlerin etkisinde kalmaktadır. Düzensiz göçmenler ülkeyi Avrupa'ya geçme noktası olarak görmektedir. Avrupa'nın göçmen kabulünde yavaş ve seçici davranması Türkiye'de olumsuz gelişmelere yol açmaktadır. Olumsuzluklara rağmen Türkiye imkanlarını seferber ederek düzensiz göçmenlerin insani imkanlardan yararlanması için her türlü tedbiri almaktadır.

\section{a. Türkiye’ye Yönelik Göçlerin Tarihsel Gelişimi}

Tarih boyunca kitlesel göçlere sahne olan Türkiye, büyük göç dalgalarıyla Osmanlı Devleti'nin dağılma döneminden itibaren karşılaşmaya başlamıştır. Cumhuriyetin ilk yıllarında ise Türkiye'den değişik nedenlerle ayrılanların yerlerine, sınırlar dışında kalan Türkler kabul edilerek farklı bölgelere yerleştirilmiştir (Goularas ve Sunata, 2015, s. 17). 1960'lı yıllardan itibaren yurt dışına iş gücü göndermeye başlayan Türkiye'de ilerleyen yıllarda eğitim, sağlık, ticaret gibi alanlarda göçün çeşitlenerek devam ettiği görülmüştür.

Uluslararası konjonktürdeki değişiklikler Türkiye'nin göç politikasını doğrudan etkilemektedir. Afganistan'ın Rusya tarafından işgali, İran devrimi, Saddam'ın faaliyetleri, Yugoslavya'nın parçalanma süreci ve Arap Baharı Türkiye'ye göçü hızlandırmıştır (Ekşi, 2014, s. 55). 1980 'lerden itibaren milyonlarca insanın zorunlu göçüne sahne olan (Gün, 2006, s. 28) Türkiye kalıcı bir göçmen nüfusa ev sahipliği yapmaya başlamıştır. Geçmişte göç veren ve geçiş alanı olarak değerlendirilen ülke, ekonomik ve siyasi istikrarsılıklar nedeniyle kitlesel göçlerle karşılaşmış (Goularas ve Sunata, 2015, s. 16) transit ülke olma yanında 
(Kaya, 2013, s. 13) göç alan bir ülke durumuna gelmiştir. Türkiye'nin stratejik konumu deniz ve kara ulaşımını kolaylaştıran imkânların bulunması (Ünal, 2014, s. 70-71) transit ülke olmasına zemin hazırlarken, ekonomik çekim merkezi olması ve göçü kolaylaştıran yasaların varlığı göçü etkileyen temel nedenler arasında gösterilmektedir (Karaca ve Saruç, 2014, s. 3).

\section{b. Türkiye’nin Göçlere Yönelik Uygulamaları}

Uluslararası hukukta kabul edilen 1951 Cenevre Sözleşmesi kabul edilen mülteci tanımının önemli bir eksiği olarak görülen coğrafya ve zaman sınırlamaları 1967 New York protokolü ile kaldırılmıştır (Buz, 2008, s. 121). Türkiye Cenevre Sözleşmesi ve 1967 Cenevre protokolünü bölgedeki siyasi karışıkığın mülteci akınına neden olacağı ve Avrupa'nın Türkiye'yi tampon bölge olarak kullanma ihtimali nedeniyle coğrafi sınırlama şerhi koyarak kabul etmiştir. Gelişmeler Türkiye'nin çekincelerini haklı çıkarmıştır. Ancak Türkiye şerhe rağmen göç hareketlerinin önüne geçememiş, coğrafi sınırlama sadece hukuki sorumluluğun doğmasını kısmen engelleyen bir unsur olmuştur (Kara ve Korkut, 2010, s. 156).

Türkiye, Avrupa'dan gelenleri mülteci olarak tanımlarken Avrupa dışından Türkiye'ye gelenleri ara formül olarak ürettiği mültecilik durumu incelenen geçici koruma sağlanan kişileri ifade eden sığınmacı olarak tanımlamaktadır. Avrupa dışından gelen mülteciler BMMYK tarafından üçüncü bir ülkeye yerleştirilmeyi beklemektedir (Buz, 2008, s. 120). BMMYK'ya yapılan başvurular aracılığıyla sığınma talebinde bulunanlar üçüncü bir ülkeye yerleştirilmektedir. BMMYK'nın temsilcileri 1960 yılından itibaren Türkiye'de mültecilerle ilgili anlaşmalara uygunluğu denetlemekte, önerilerde bulunmakta, sosyal ve ekonomik hakların gelişmesine yönelik tedbirler almaya çalışmaktadır. Türkiye, uyguladığı mültecilik prosedüründeki hukuki boşluğu doldurmak amacıyla 1994'de hazırlanan iltica yönetmeliği ile (Goularas ve Sunata, 2015, s. 19-28) kendi politikalarını belirlemiş, Avrupa dışından gelen sığınmacılara mülteci statüsü vermemiştir (Buz, 2008, s. 121). 30 Kasım 1994 Sayı 22127 Türkiye'ye Illtica Eden veya Başka Bir Ülkeye İltica Etmek Üzere Türkiye'den İkamet İzni Talep Eden Münferit Yabancılara Uygulanacak Usul ve Esaslar 6. madde, Türkiye'ye sığınan yabancıların ikamet izinlerinin 1951 Cenevre Sözleşmesi ve 31 Ocak 1967 protokolü doğrultusunda verileceğini hükme bağlamıştır. İlgili yönetmeliğin 8. maddesi sınırlara sığınma hareketlerinin dayanması halinde göçmenlerin sınırları geçmemesi için gerekli tedbirler alınmasını öngörmekte, 12. maddesi ise ülkeye girmeleri halinde sığınmacıların mümkün olduğu oranda "örf ve adetlerine uygun olarak yerleştirilmelerine özen gösterilir" denilmektedir. 26. maddesinde savaş veya silahlı çatışma nedeniyle ülkeye gelenlerin karışıklığın sona ermesini takiben geldikleri ülkeye gönderilmelerini öngörmektedir (Resmi Gazete, Sayı: 22127 30.11.1994). 2000'li yıllardan itibaren göç politikalarını AB mevzuatına göre düzenlemeye başlayan Türkiye, 2004 yılında Uluslararası Göç Örgütüne (UGÖ) üye olmuş, düzensiz göç ve insan ticaretinin önlenmesi alanlarında etkin çalışmalar yapmaya başlamıştır (Goularas ve Sunata, 2015, s. 21).

Göç İdaresi Genel Müdürlüğü 2013 tarihinde Yabancılar ve Uluslararası Koruma Kanunu ile kurulmuş olup İçişleri Bakanlığına bağlıdır (İçişleri Bakanlığı Göç İdaresi Genel Müdürlüğü, Genel Müdürlük). Göç politikalarını uygulayarak kurumlar arası koordinasyon sağlamak, 
yabancıların Türkiye'ye giriş, kalış ve çıkışlarını, sınır dışı edilme durumlarını ve uluslararası koruma gibi konularda çalışmaktadır (İçişleri Bakanlığı Göç Idaresi Genel Müdürlüğü). Türkiye'de 6458 Sayılı Yabancılar ve Uluslararası Koruma Kanunu (YUKK), 11.04.2013 tarih ve 28615 sayılı Resmi Gazetede yayımlanmıştır (İçişleri Bakanlığı Göç İdaresi Genel Müdürlüğü, Yabancılar ve Uluslararası Koruma Kanunu). Kanunun amacı, yabancıların Türkiye'ye göçünü ve koruma istenmesi halinde bunun kapsamını düzenlemektir (Yabancılar ve Uluslararası Koruma Kanunu).

Türkiye Ulusal Eylem Planı ile göç konusunda sığınma başvurusunda bulunanlara yer sağlamak üzere alt yapıyı ve mevzuatı geliştirmelidir. Coğrafi sınırlamanın kaldırılması ve Cenevre Sözleşmesini nasıl, ne zaman uygulayacağı belirlenmelidir (Ulusal Eylem Planı, 2019). Göçün çeşitleri, artış hızı ve Avrupa İnsan Hakları Mahkemesi (AiHM) kararları yasanın hazırlanmasında göz önünde bulundurulmuştur. Türkiye coğrafi sınırlamayı kaldırmak için Avrupa'nın külfet paylaşımını kabul etmesi ve alt yapının Türkiye'ye mülteci akınını teşvik etmeyecek şekilde düzenlenmesi şartını ileri sürmektedir. Kanunun 61. maddesi mülteciyi "Avrupa ülkelerinde meydana gelen olaylar nedeniyle; ırkı, dini, tabiiyeti, belli bir toplumsal gruba mensubiyeti veya siyasi düşüncelerinden dolayı zulme uğrayacağından haklı sebeplerle korktuğu için vatandaşı olduğu ülkenin dışında bulunan ve bu ülkenin korumasından yararlanamayan" ya da yararlanmak istemeyen kendi ülkesi dışında bulunan ülkesine dönemeyen veya dönmek istemeyen kişiler olarak tanımlamaktadır. 62. maddeye göre, Avrupa dışından gelen ve ülkelerine dönmek istemeyen vatansız kişiler, gerekli işlemler yapıldıktan sonra şartlı mülteci statüsü verilerek üçüncü ülkeye yerleştirilinceye kadar Türkiye'de kalmasına izin verilen kişiler olarak tarif edilmektedir (Resmi Gazete Tarih: 11.4.2013 Sayı: 28615).

Uygulamada Türkiye, Avrupa dışından gelerek üçüncü ülkeye geçme başvurusunun değerlendirilmesine kadar geçen süre için sığınma hakkı vermektedir. Sığınma talebi reddedilen kişiler talepte bulundukları ülkeyi terk etmek zorunda olduklarında sığınma başvurusu reddedilenleri sınır dışı etmektedir (Goularas ve Sunata, 2015, s. 28). 2011 yılından itibaren Suriye'den Türkiye'ye gelen sığınmacılara uygulanan prosedür coğrafi sınırlama ilkesiyle uyuşmamaktadır. Ortaya çıkan bu çelişkiyi önlemek için uluslararası hukukta yeri olmayan Türk halkının yardımseverlik ve misafirperverliğini ön plana çıkaran "misafir" ifadesi kullanılmışsa da sürenin uzaması ve karşılaşılan sorunlar misafir tanımlaması yerine "geçici koruma" terimi kullanılarak uygulama, hukuki yapıya kavuşturulmak istenmiştir. Geçici koruma, sığınmacı sorunlarının nasıl çözüleceği konusuna açıklık getirmemektedir.

Türkiye ve $A B$ arasında Geri Kabul Anlaşması imzalanmış ve buna göre Türkiye, toprakları üzerinden $A B$ ülkelerine yasadışı yollarla gitmiş olan diğer ülkelerin vatandaşlarını geri alacaktır (Avrupa Birliği Bakanlığı, 2013). Türkiye ile AB ülkeleri arasında yapılan Geri Kabul Anlaşması'na göre Danimarka ve İrlanda dışındaki tüm $A B$ ülkelerine kaçak yollarla giren göçmenlerin Türkiye'ye gönderilebilmesi öngörülmektedir. Anlaşmanın son aşamasında vatandaşlık bağına bakılmaksızın Avrupa, Türkiye üzerinden kendi topraklarına giren istemediği her göçmeni Türkiye'ye gönderebilecektir. Türkiye geri kabul anlaşmasıyla üçüncü ülke vatandaşlarını veya vatansızları kabul etmeyi taahhüt etmiştir (Resmi Gazete 
Sayı 290762 Ağustos 2014). Türkiye, Avrupa'nın Türkiye’yi göçmenler önünde bir baraj olarak görmek istediğini düşünmekte (Deutsche Welle Türkçe, 2016) ve coğrafi çekincenin kaldırılması halinde ortaya çıkacak mali külfetten endişelenmektedir. Türkiye ekonomisi kendi vatandaşlarının istihdamını sağlamak için uluslararası sermaye ve kredilere ihtiyaç duyarken, coğrafi sınırlamanın kaldırılması sonucunda muhtemel mülteci akınını önlemek için veya etkilerini hafifletmek için mali kaynaklara ihtiyaç duyacaktır (Barkın, 2014, s. 357).

\section{c. 21. Yüzyılın Başından İtibaren Türkiye'ye Yönelen Göçlerin Yoğunlaşma Nedenleri}

2000'li yıllarda II. Dünya Savaşı'ndan sonra yaşanan en büyük mülteci kriziyle Türkiye'ye gelen göçmenler sorunlarını da birlikte taşımıştır. Türkiye, Suriye iç savaşından kaçanların yarısından fazlasına, düzensiz göçmenlere, insan ticareti mağdurlarına, sığınmacılara kısaca memleketlerinden ekonomi veya güvenlik nedeniyle kopan milyonlarca insana ev sahipliği yapmaktadır. Insan kaçakçılığı faaliyetlerinde bir kısmı Türkiye üzerinden Avrupa'ya yönelmekle birlikte önemli bir kısmının da Türkiye'nin komşularına göre ekonomik ve sosyal açıdan daha iyi konuma sahip olmasından dolayı ülkede kalmayı hedeflediği görülmektedir. Insan kaçakçıı̆ı̆ından Türkiye'ye sığınma talebinde bulunanların büyük bölümü (Aça, 2010) Ortadoğu, Afrika ve Orta Asya vatandaşlarıdır. Türkiye; Moldova, Romanya, Rusya, Gürcistan gibi eski doğu bloğu ülkelerinin kaçak çalışmak amacıyla seçtikleri hedef ülke (Barkın, 2014, s. 352) iken Almanya, ABD ve İngiltere vatandaşlarının yoğun olarak yerleşmeye başladığı ülkeler arasına girmiştir.

Dünyada yaşanan çatışma, şiddet ve zulüm nedeniyle yer değiştirmek zorunda kalan insanların sayısı rekor seviyeye ulaşmıştır. Türkiye, dünyada en fazla mülteciye ev sahipliği yapan ülke olmaya devam etmektedir (United Nations Refugee Agency [UNHCR], 2021b). Mültecilerin komşu ülkelerin kapılarına dayanması gerçeği Türkiye'de de yaşanmış, Arap Baharından sonra Arap ülkelerinden Türkiye'ye yönelik yoğun bir mülteci akımı oluşmuştur. Gelen sığınmacıların büyük bir bölümü yasal olmayan yollarla gelmeyi tercih etmektedir. Türkiye ile Suriye arasında 911 kmlik sınırda tabi engellerin olmaması kaçak geçişlere zemin hazırlamaktadır. Mültecilerin bir kısmının Türkiye'deki vatandaşlarla akrabalık bağlarının bulunması sorunu bir ölçüde kolaylaştırmaktaysa da 1921 Ankara Anlaşması'nın birbirinden kopardığı insanlar zaten sınırı geçmek için izin almaya ihtiyaç duymamaktaydı (Boyraz, 2015, s. 37-45). Suriye'de çatışma 2011 'de başladığından beri Türkiye, Suriyeli mültecilere koruma sağlamıştır. Suriyelilerin kendi bölgelerine gelmesine izin verip onlara yardım etmek için finansal kaynaklar ve sosyal hizmetler tahsis eden diğer komşu ülkelerde olduğu gibi toplum, olumsuz ekonomik ve sosyal etkilere maruz kalmıştır (Ostrand, 2015, s. 262). Türkiye diğer sığınmacılara olduğu gibi Suriyelilere de ücretsiz sağlık hizmeti yanında gıda, barınma, mesleki eğitim ve örgün eğitime erişim sağlamaktadır. Suriyeliler yarım kalmış eğitimlerini her seviyede tamamlama imkânına sahip olmaktadır. Ancak resmi kamplar dışında ülkenin değişik bölgelerine dağılan Suriyelilere barınma yardımı yapılmamaktadır (Boyraz, 2015, s. 44). Türkiye'de 4 milyon mülteci ve sığınmacı olduğu bunun 3,6 milyondan fazlasının Suriyelilerden oluştuğu ve onların Türkiye genelinde 81 ilde yaşadıkları belirtilmiştir (United Nations Refugee Agency [UNHCR], 2021a). Böylece Türkiye, barındırdığı sığınmacı sayısıyla 61 ülkenin nüfusundan daha fazla sığınmacıya ev sahipliği yapmaya başlamıştır (Çoğalan, 2017). Bu orana resmi makamlara henüz başvuruları 
güvenlik soruşturmaları nedeniyle tamamlanamamış kişiler dâhil edilmemiştir. Suriyelilerin de aralarında yer aldığı sığınmacıların önemli bir kısmında üçüncü bir ülkeye mülteci müracaatı yapma şansının kaybolacağı gerekçesi ile kayıt altına girmekten kaçınmanın yoğun olduğu görülmektedir. Türkiye'de bulunan Suriyeli sığınmacılar, Türkiye nüfusunun \% 4'ünü aşmış yerleşik göçmen konumuna evirilmiştir (Boyraz, 2015, s. 35). Türkiye'de bulunan Suriyeli sığınmacıların yarısı bebek ve çocuklardan oluşmaktadır (Deutsche Welle Türkçe, 2017). Yasadışı yöntemlerle Türkiye'ye girmiş bulunan ve kayıt altına alınamayan sığınmacıların sayısının 500 binden fazla olduğu düşünülmektedir. Diğer yandan $A B$ ülkelerinde uygulanan sıkı vize sistemi nedeniyle mültecilerin kabul şansının yok denecek kadar azalması insan kaçakçılığına zemin hazırlamaktadır ve $A B^{\prime}$ de mültecilerin tamamının 1,5 milyon civarında olduğu görülmektedir (Deutsche Welle Türkçe, 2016).

\section{d. Göçmenlere Yönelik Verilen Hizmetler ve Karşılaşılan Zorluklar}

Ulaşım ve iletişimdeki gelişmeler düzensiz göçü tetiklemekte ve kitlesel göç hareketlerinde büyük artış yaşanmaktadır. Türkiye özellikle Suriyeli sığınmacıları zorla ülkelerine göndermekten kaçınmıştır. Transit ülke olması nedeniyle yabancı nüfus hareketi yanında ekonomik nedenlerle yasa dışı yollardan Türkiye'ye girenlerin sayısında önemli bir artış yaşanmaktadır (Karaca ve Saruç, 2014, s. 3). Türkiye, sığınmacılara Yugoslavya olaylarında $A B$ devletlerinin de uyguladığı bir sistem olan, acil durumlar için önerilen bir yöntem olarak kabul edilen geçici koruma statüsü uygulamaktadır. Bu kapsamda giriş çıkışlarına izin verilen kişilere sunulan hizmetler kamu kuruluşları, yerel yönetimler ve sivil toplum kuruluşları ile uluslararası kuruluşlar eliyle yürütülmektedir. Dağınıklık gösteren bu hizmetlerde zaman zaman karışıklık yaşanmaktadır. "Misafir" statüsü olarak da adlandırılan bu uygulama sığınma talebinde bulunanların müracaatlarının neticelenmesinde sürenin uzaması ekonomik varlıklarını ve statülerini geride bırakıp gelen insanlar açısından çeşitli sorunlarla (dil, ekonomi, eğitim, sağlık vb.) karşılaşmalarına yol açmaktadır. Sığınma talebi kabul edilmeyenler BMMYK'nın ilgi alanı dışına çıktıklarından Türkiye'de kaçak kalmaya devam etmektedir (Buz, 2008, s. 123). Türkiye 2019 verilerine göre geçici barınma merkezlerinde 108 binin üzerinde yabancı barındırmaktadır. Merkezler dışında ise 3,5 milyondan fazla geçici korumaya sahip kişi bulunmaktadır. Bu merkezlerde eğitimden sağlık hizmetlerine ibadethanelerden marketlere kadar çeşitli hizmetler verilmektedir (İçişleri Bakanlığı Göç İdaresi Genel Müdürlüğü, Geçici Korumamız Altındaki Suriyeliler). Türkiye Avrupa'nın istemediği göçmenler açısından tampon bölge olarak görülmekte, AB'nin sınırlarını korumak adına büyük maddi külfet altına girmektedir.

Gelişmemiş ülke vatandaşlarının daha iyi hayat şartlarına kavuşmak amacıyla çıktıkları yolculukta gelişmiş ülkelere götürülmesi karşılığında para karşılığı insanları başka ülkelere götürme işlemi olan insan kaçakçılı̆̆ (Aça, 2010) Türkiye'nin önemli güvenlik sorunlarından biri haline gelmiştir. Türkiye üzerinden yapılan düzensiz göçün \% 85'inin kaçakçılar aracılığıyla yapıldığını çalışmalar ortaya koymuştur (Goularas ve Sunata, 2015, s. 25). Türkiye'de transit geçişlerin terör örgütlerine faaliyet alanı oluşturduğu, kaçak çalışanlar nedeniyle vergi kaybına yol açtığı, göçmenlerin suçlara karıştığı, hazinenin yapılan masraflar nedeniyle zarara uğradığı ve döviz çıkışına neden olduğu fikri gündeme getirilmektedir (Yılmaz, 2014, s. 1697). 
Türkiye'ye yasa dışı yollardan giriş yapanların önemli bir kısmı ülkede kalmayı amaçlamaktadır. Sığınmacıların sayısının giderek artması, sivil toplum kuruluşlarının ihtiyaçları karşılamakta zaman zaman zorlanması ve bir kısım yasadışı işlere karışanların sığınmacı kaynaklı olması yabancılara yaklaşımı nispeten etkilemektedir. Örneğin sosyal dışlanma, ayrımcılık, yabancı düşmanlığı, ötekileştirme, kayıt dışı çalışma ve yoksullukla mücadele etmek durumunda kalmaktadırlar (Ünal, 2014, s. 68). Türkiye'deki sığınmacılara ekonomik kaygılarla yaklaşanlar ise ekonominin bozulacağı, devletin kendi vatandaşlarına vermediği hizmeti sığınmacılara verdiği kanaatini yaygınlaştırmaya çalışmaktadır. Diğer taraftan özelde Suriyeli sığınmacıların ülkelerini savunmaktan kaçan vatan haini oldukları ve ülke çıkarlarıyla örtüşmedikleri ifade edilerek maliyet unsuru üzerinden, ülkede bulunmalarına karşı çıkılması yaygınlaşmaktadır. Mültecilerin ülkelerine gitmeleri gerektiğini düşünenler Suriyelilerin dönmek isteseler bile ülkelerindeki büyük yıkım nedeniyle dönüşün gecikeceğini savunmaktadır (Bozkurt, 2018). Geri dönüş için alınan özendirici tedbirlere rağmen, İçişleri Bakan Yardımcısı İsmail Çataklı’nın Mayıs 2021 basın bilgilendirme toplantısında yaptığı açıklamaya göre, 436 bin 947 Suriyeli ülkesine geri dönmüştür (TC İçişleri Bakanlığı, 04.05.2021). Suriyeli sığınmacıların Türkiye'de iş imkânlarından pay almaya çalışması medyada çıkan haberlerin de etkisiyle nefret söylemine dönüşmektedir. Özellikle tarım ve inşaat sektöründe 500 binden fazla Suriyelinin yer aldığı görülmekte (Bozkurt, 2018) yanlış anlaşılmalar Suriyelilerin Türkiye'ye yerleştirileceği fikrini oluşturmakta ve ülkede mevcut olmayan yabancı düşmanlığına zemin hazırlamaktadır.

Sınır dışı edilme konusunda ise AïHM Türkiye'nin coğrafi ayrıcalık uygulamasını Avrupa İnsan Hakları Sözleşmesinin 18. maddesine aykırı bulmaktadır. Mahkeme 2008'den itibaren Türkiye tarafından hayata geçirilen sınır dışı işlemlerini ve iade kararlarının Avrupa Insan Hakları Sözleşmesine aykırı olduğu gerekçesiyle Türkiye aleyhine çok sayıda karar vermiştir (Ekşi, 2014, s. 58-69). Bunu sözleşmeye taraf devletler sınır dışı edecekleri kişilerin yaşam hakkının güvende olduğundan emin olmalıdır (Danıştay, Avrupa İnsan Hakları Sözleşmesi) hükmüne dayandırmaktadırlar. Ancak Türkiye, coğrafi sınırlamayı kaldırması halinde kaynak ülke ile Batı arasında tampon bölge olacağını düşünmektedir (Kartal ve Baş̧̧ı, 2014, s. 284).

\section{Sonuç}

Dünyanın en eski sosyal hareketlerinden olan göç olgusu yıkıcı etkileri yanında insanlığa yeni ufuklar da açmıştır. Küreselleşen dünyada gelişmelerden kısa sürede haberdar olma imkanının yakalanması, insanların refah seviyesi yüksek ülkelerde yaşama isteğini artırmaktadır. Göçmenler göç ettikleri ülkeleri yetişmiş insan gücünden mahrum bırakırken, göçler coğrafi açıdan ağırlıklı olarak doğu-batı veya güney-kuzey yönünde yapılmaktadır. Günümüzde yaşanan göç hareketleri, gidilen ülkelerin sindirme kapasitelerini zorlamaktadır.

Göç insanlığın ortak sorunu olarak değerlendirilip çözüm üretilmesi gereken bir konudur. Yaşanan insanlık dramları uluslararası basında yer alırken, konunun insani boyutuyla ilgileniliyor gibi davranılmaktadır. Ancak devletlerin çoğu göçün nedenlerini ortadan kaldırmaya dönük çalışmalar yerine sınır güvenliklerini artırarak tedbir almaya çalışmaktadır. Bütün teknolojik imkanlar kullanılmasına rağmen güvenlik merkezli yaklaşımlar sınırlara dayanan göçmenleri durduramamaktadır. Buna karşın insan kaçakçıları kısa sürede yeni rotalar oluşturarak kazançlarını artırmaktadır. Göçmenler gittikleri ülkelerde ekonomik ve 
politik olarak sömürülmeye açık olmakta ve kültürlerini koruyamamaktadır. Bu yüzden sosyal bir olgu olan göçün, güvenlik kaygıları dışında insani temelli ve uzun vadeli değerlendirilmesi gereken bir konu olduğu özümsenmelidir. Göçmenlerin nihai hedefi olan Avrupa ülkelerinin çoğu sorumluluk almaya yanaşmamakta ve yetişmiş insan devşirmenin yollarını meşrulaştırmaya çalışmaktadır. İnsanların Avrupa'ya ulaşmak için geçiş noktası olarak gördüğü ülkelerde ise, idarecilerin iyi niyetli yaklaşımlarına rağmen bu olgu sosyal ve ekonomik tepkilere yol açabilmektedir.

Türkiye ulusalararası güçlerin kendi aralarında yaptıkları alan mücadelesinden doğrudan etkilenmektedir. Suriye, Irak ve Afganistan başta olmak üzere iç karışıklık yaşanan ülkelerden güvenlik gerekçesiyle ortaya çıkan göçlerin külfetini ilk etapta Türkiye üstlenmek zorunda kalmaktadır. Ancak düzensiz göçten kaynaklanan ekonomik külfet paylaşılmalıdır. Türkiye insani gerekçelerle kendine sığınanlara kucak açmıştır. Dünyada gelinen noktada ise göçmenler adeta sratejik bir savaşın unsuru gibi kullanılmaya başlamıştır. Türkiye'nin yakın çevresinde ortaya çıkan gelişmeler Türkiye'deki düzensiz göçmenlerin sayısının artacağını göstermektedir. Özellikle Suriye'deki gelişmeler Türkiye üzerinde baskı aracı olarak kullanılmaya çalışılmaktadır. Binlerce kilometre uzaktan gelen güçler hak iddia edebilirken Türkiye'nin güvenlik endişeleri görmezlikten gelinmeye çalışılmaktadır. Bu yüzden Türkiye'nin de içinde bulunduğu ülkeler düzensiz göçün ekonomik, sosyal ve kültürel yükünü çekmeye zorlanmaktadır. Kısacası göçün nedenlerinin ekonomik eşitsizlik ve insan hakları ihlalleri olduğu dikkate alındığında, orta ve uzun vadede kaynak ülkelere yönelik uygulanacak politikalarla düzensiz göç konusu kaynağında çözümlenmelidir. Buna ilave olarak ülkelerine geri dönmek isteyen sığınmacılar teşvik edilmelidir. Mevcut durum, gelişmekte olan ülkelerin sığınmacılardan kaynaklanan nedenlerle büyük bedeller ödemesine yol açmaktadır. Bu yüzden hedef konumundaki zengin ülkelerin, kaynak konumundaki ülkelere yönelik kalkınma planlarını gözden geçirmesi gerekmektedir.

\section{"Göç Olgusunun Çok Boyutlu Etkileri ve Türkiye'ye Yansımaları" Başıkı Makalenin Araştırma ve Etik Beyanı Bilgileri}

\section{Bu çalışma "Araştırma ve Yayın Etiği" değerlerine uygun olarak hazırlanmıştır.}

\begin{tabular}{l|l}
\hline Bilgilendirme & $\begin{array}{l}\text { Çalışma herhangi bir bildiri veya tez benzeri çalışmadan üretim } \\
\text { değildir. }\end{array}$ \\
\hline $\begin{array}{l}\text { Yazar Çıkar } \\
\text { Çatışması Beyanı }\end{array}$ & Çalışmada herhangi bir çıkar çatışması bulunmamaktadır. \\
\hline $\begin{array}{l}\text { Yazar Katkı } \\
\text { Oranı Beyanı }\end{array}$ & $\begin{array}{l}\text { Çalışmayı şahsım Ayşegül GÜLER olarak tek başıma hazırladığımı } \\
\text { beyan ederim. }\end{array}$ \\
\hline $\begin{array}{l}\text { Teşekkür } \\
\text { Çalışmada teşekkür gerektiren bir durum bulunmamaktadır. }\end{array}$
\end{tabular}




\section{Kaynakça}

Aça, F. (2010). Göçmenler Ülkesi Türkiye. http://www.ntv.com.tr/turkiye/gocmenler-ulkesiturkiye,v7FYi8eNWUWbejxPodwcvA, Erişim Tarihi:12.08.2017.

Avrupa Birliği Bakanlığı (2013). Türkiye AB Vize Muafiyeti Süreci ve Geri Kabul Anlaşması Hakkında Temel Sorular ve Yanıtları. https://www.ab.gov.tr/files/pub/turkiye_ab_vize_muafiyeti_sureci_ve_geri_kabul _anlasmasi_hakkinda_temel_sorular_ve_yanitlari.pdf, Erişim Tarihi:15.10.2019.

Barkın, E. (2014). 1951 Tarihli Mülteciliğin Önlenmesi Sözleşmesi. Ankara Barosu Dergisi, 1, 333-360.

Berti, B. (2015). The Syrian Refugee Crisis: Regional and Human Security Implications. Strategic Assessment, 17(4), 41-53.

Bigo, D. (2002). Security and Immigration: Toward a Critique of the Governmentality of Unease. Alternatives 27, Special Issue, 63-92.

Borjas, G. J. (1994). The Economics of Immigration. Journal of Economic Literature, Vol. 32, 1667-1717.

Borjas, G. J. (1995). The Economic Benefits From Immigration. Journal of Economic Perspectives, 9(2), Spring, 3-22.

Boubtane, E., Coulibaly, D. and Rault, C. (2013). Immigration, Unemployment and GDP in the Host Country: Bootstrap Panel Granger Causality Analysis on OECD Countrie. Ekonomic Modelling 33, 261-269.

Boyraz, Z. (2015). Türkiye'de Göçmen Sorununa Örnek Suriyeli Mülteciler. Journal of World of Turks, $7(2), 35-58$.

Bozkurt, K. (2018). Suriye İ̧̧ Savaşı: Savaşın Yarattığı Mültecilik Akınının Türkiye ve Avrupa Birliği'ne Yansımaları. Türkiye Siyaset Bilimi Dergisi, 1(1), 57-70.

Buz, S. (2008). Türkiye Sığınma Sisteminin Sosyal Boyutu. TBB Dergisi, 76, s.120-130.

Buzan, B. (1991). New Patterns of Global Security in the Twenty-First Century. International Affairs, Jul, 67(3).

Castles, S. ve Miller, M. J. (1998). The Age Of The Migration: International Population Movements in the Modern World, London: Macmillan Press.

Çakır, M. (2013). Internet Haberciliğinde Yasadışı Göç Sorunu (Ocak 2011-Nisan 2012). Online AcademicJournal of Information Technology, Bahar, 4(12), 105-124. 
Çoğalan, S. (2017). Türkiye'deki Sığınmacı Sayısı 61 Ülkenin Nüfusundan Fazla. https://www.aa.com.tr/tr/turkiye/turkiyedeki-siginmaci-sayisi-61-ulkeninnufusundan-fazla/751580, Erişim Tarihi:05.12.2018.

Danıştay, Avrupa Insan Hakları Sözleşmesi. https://www.danistay.gov.tr/upload/avrupainsanhaklarisozlesmesi.pdf, Erişim Tarihi:11.06.2019.

Danıştay, Mültecilerin Hukuki durumuna Dair Sözleşme. (t.y.) http://www.danistay.gov.tr/upload/multecilerin_hukuki_durumuna_dair_sozlesm e.pdf, s.180, Erişim Tarihi:12.08.2017.

Deutsche Welle Türkçe, (2016). AB Komisyonu: Geri Kabul Anlaşması Yürürlükte. http://www.dw.com/tr/ab-komisyonu-geri-kabul-anla\%C5\%9Fmas\%C4\%B1y\%C3\%BCr\%C3\%BCrl\%C3\%BCkte/a-19299023 , Erişim Tarihi:10.10.2017.

Deutsche Welle Türkçe, (2017). Türkiye'de Mülteci Sayısı Tahmin Edilenden Yüksek. http://www.dw.com/tr/t\%C3\%BCrkiyede-m\%C3\%BClteci-say\%C4\%B1s\%C4\%B1tahmin-edilenden-y\%C3\%BCksek/a-39323369 , Erişim Tarihi:11.10.2017.

Duleep, H. O. (1994). Social Security and the Emigration of Immigrants. Washington: Program for Research on Immigration Policy.

Ekşi, A. (2009). Mülteci ve Göçmenlerde Psikopatoloji. 11.Anadolu Psikiyatri Günleri Tam Metni Kitabı.

Ekşi, N. (2014). İltica Talepleri Reddedilerek Türkiye'den Sınır Dışı Edilmelerine Karar Verilen Yabancılara İlişkin AiHM Kararlarının Yabancılar ve Uluslararası Koruma Kanununa Etkisi. TAAD, 5(19), Ekim, 53-99.

Fargues, P. (2014). Europe Must Take On Its Share Of The Syrian Refugee Burden, But How?. Migration Policy Centre, February/01, 1-5. file:///C:/Users/Kmu/Desktop/göç\%20ing/MPC_PB_2014_01.pdf , Erişim Tarihi:15.02.2017.

Goularas, G. B. ve Sunata, U. (2015). Türk Dış Politikasında Göç ve Mülteci Rejimi. Hacettepe Üniversitesi İletişim Fakültesi Kültürel Çalışmalar Dergisi, 2 (1), 12-40.

Gün, Z. (2006). Psikolojide, Göç Çalışmalarındaki Metodolojik Problemler ve Çözüm Önerileri. Türk Psikoloji Bülteni, Temmuz, 12(38), 27-41.

Hâkimler ve Savcılar Kurulu, (t.y.) Insan Hakları Evrensel Beyannamesi. https://www.hsk.gov.tr/Eklentiler/Dosyalar/9a3bfe74-cdc4-4ae4-b876-

8cb1d7eeae05.pdf, Erişim Tarihi:14.04.2019.

International Organization for Migration, (IOM) (2019). World Migration Report 2020, https://publications.iom.int/system/files/pdf/wmr_2020.pdf,

Erişim Tarihi:12.05.2020. 
İçişleri Bakanlığı Göç İdaresi Genel Müdürlüğü, Göç Idaresi Genel Müdürlüğü Hizmet. https://www.icisleri.gov.tr/goc-idaresi-genel-mudurlugu-hizmet, Erişim Tarihi:10.12.2019.

İçişleri Bakanlığı Göç İdaresi Genel Müdürlüğü, Göç İdaresi Genel Müdürlüğü Mevzuatı. https://www.goc.gov.tr/gigm-mevzuati, Erişim Tarihi:19.04.2019.

İçişleri Bakanlığı Göç İdaresi Genel Müdürlüğü, Geçici Korumamız Altındaki Suriyeliler. https://www.goc.gov.tr/gecici-korumamiz-altindaki-suriyeliler, Erişişim Tarihi:01.08.2019.

İçişleri Bakanlığı Göç Idaresi Genel Müdürlüğü, Genel Müdürlüğün Görevleri. https://www.goc.gov.tr/genel-mudurlugun-gorevleri, Erişim Tarihi:10.02.2019.

Kara, P. ve Korkut, R. (2010). Türkiye'de Göç, Illtica ve Mülteciler. Türk İdare Dergisi, 467, 153-162.

Karaca, N. ve G., Saruç, S. (2014). Türkiye ve Avrupa Birliğine Aday Geçiş Ekonomilerinde Uluslararası Göç Trendleri. International Conference On Eurasian Ekonomies, 1-9.

Kartal, B. ve Başçı, E. (2014). Türkiye'ye Yönelik Mülteci ve Sığınmacı Hareketleri. CBÜ Sosyal Bilimler Dergisi, 12(2), 275-299.

Kaya, A . (2013). Türkiye-AB Üyelik Müzakerelerinde Yasadışı Göçün Önemi ve Yansımaları. Türk İdare Dergisi,79, 455, 13-26.

Keleş, M. (2017). Dünyada 710 Milyon Kişi Göç Etmek İstiyor. https://www.aa.com.tr/tr/dunya/dunyada-710-milyon-kisi-goc-etmekistiyor/859354, Erişim Tarihi:01.09.2017.

Kirişci, K. (2014). Syrian Refugees and Turkey's Challenges: Going Beyond Hospitality. Washington: Brookings, 1775 Massachusetts Avenue, N.W., Washington, D.C. 20036.

Kömürcü, Y., Özsoy R. ve Çobanoğlu A. (2011). Kadın Sığınmacılar: Uluslararası Göçün Sessiz Tanıkları, Onlar Bizim Hemşehrilerimiz, Erol Esen, Zeliha Yazıcı (Ed) içinde, Uluslararası Göç ve Hizmetlerin Kültürlerarası Açılımı. Ankara: Siyasal Kitabevi.

Mevzuat, Yabancilar ve Uluslararası Koruma Kanunu. https://www.mevzuat.gov.tr/MevzuatMetin/1.5.6458.pdf, Erişim Tarihi:19.04.2019.

Migration Policy Institue (MPI). International Governance. https://www.migrationpolicy.org/topics/international-governance, Erişim Tarihi:10.06.2019.

Mülteciler Derneği (4 Aralık 2019). Türkiye'deki Suriyeli Sayısı, https://multeciler.org.tr/turkiyedeki-suriyeli-sayisi/ , Erişim Tarihi:05.12.2019. 
Ostrand, N. (2015). The Syrian Refugee Crisis: A Comparison of Responses by Germany, Sweden, the United Kingdom, and the United States. Journal on Migration and Human Security,3(3), 255-279.

Özdal, B. (2008). Türkiye'nin Avrupa Birliğine Üyelik Süreci Bağlamında Avrupa Birliğinin Göç Politikası ve İstihdam Stratejisi, "İ̧̧, Güç". Endüstri iliş̧kiler ve Insan Kaynakları Dergisi, 10(3), 89-121.

Resmi Gazete (1994). 30 Kasım 1994 Sayı:22127 Türkiye’ye Illtica Eden veya Başka Bir Ülkeye İltica Etmek Üzere Türkiye'den İkamet İzni Talep Eden Münferit Yabancılara Uygulanacak Usul ve Esaslar Yönetmeliği.

Resmi Gazete (2013). 11 Nisan 2013 ve Sayı:28615 Yabancılar ve Uluslararası Koruma Kanunu https://www.mevzuat.gov.tr/MevzuatMetin/1.5.6458.pdf, Erişim Tarihi:10.04.2019.

Resmi Gazete (2014). 2 Ağustos 2014 ve Sayı:29076 https://www.resmigazete.gov.tr/eskiler/2014/08/20140802-1.htm, Erişim Tarihi:10.04.2019.

Türkiye Cumhuriyeti İçişleri Bakanlığı (2021). https://www.icisleri.gov.tr/bakan-yardimcimizsn-ismail-catakli-tarafindan-aylik-basin-bilgilendirme-toplantisi-gerceklestirildi-4-52021, Erişim Tarihi:07.08.2021.

Türkiye Cumhuriyeti Avrupa Birliği Bakanlığı, Ulusal Eylem Planı (2019). https://www.ab.gov.tr/files/ceb/Ulusal_Eylem_Planlari/ulusal_eylem_plani_2016_ 2019_tr.pdf, Erişim Tarihi:28.07.2019.

Türk Dil Kurumu (2000). Okul Sözlüğü, Ankara: Türk Dil Kurumu Yayınları.

Ulukan, N. C. (2013). Göçmenler İçin Kaçış Yok: Göç Politikaları ve Göçmen Emeği. Eğitim, Bilim, Toplum Dergisi, 11(44), 32-47.

United Nations, Statistical Commission (2017). Handbook on Measuring International Migration Through Population Censuses, https://unstats.un.org/unsd/statcom/48th-session/documents/BG-4a-MigrationHandbook-E.pdf, Erişim Tarihi: 04.04.2021.

United Nations Refugee Agency, (2021a). Turkey Operational Update February- March 2021, https://www.unhcr.org/tr/wp-content/uploads/sites/14/2021/05/UNHCRTurkey-Operational-Update-February-March-2021.pdf, Erişim Tarihi:02.04.2021.

United Nations Refugee Agency, (2021b). Refugees and Asylum Seekers in Turkey, https://www.unhcr.org/tr/en/refugees-and-asylum-seekers-in-turkey, Erişim Tarihi:04.04.2021.

Ünal, S. (2014). Türkiye'nin Beklenmedik Konukları: "Öteki” Bağlamında Yabancı Göçmen ve Mülteci Deneyimi. Journal of World of Turks, 6(3), 65-89. 
Yılmaz, A. (2014). Uluslararası Göç: Çeşitleri, Nedenleri, Etkileri, Turkish Studies, International Peridical For The Languages. Literature and History of Turkish or Turkic Volume, 9(2), 1685-1704. 


\title{
Multidimensional Effects of Migration and Its Reflections on Turkey
}

\author{
Ayșegül GÜLER
}

\section{Extended Abstract}

Migration is an ongoing event in history. The 1948 Universal Declaration of Human Rights defended the rights of those who were persecuted. The "Convention on the Legal Status of Refugees", which came into force in 1954 to provide solutions to mass refugee movements in the European continent, is known as the first serious undertaking. The Geneva Convention sets standards for international law on European refugees affected by war. The negativities in the Geneva Convention that exclude refugees outside Europe are eliminated with the 1967 supplementary protocol. Thus, the door was opened to seeing migration movements as the general problem of the world, and in theory the problems faced by refugees were tried to be fixed. $3.5 \%$ of the world population is a migrant. For this reason, some describe the process as "the age of immigration". $80 \%$ of refugee movements in the world are experienced in underdeveloped or developing countries. Despite the perception created despite the fact that industrialized European countries constantly raise their voices on migration, it is thought that they are not under serious threat of migration. Migration affects both the source country and the destination country deeply in terms of its effects. It is one of the most common cases that asylum seekers are excluded by the locals in the countries they go.

Turkey is an important country for immigration. Some of the countries Turkey is neighbouring often force refugee boats to return to Turkey, confiscate their engines, food and leave them to die in the open sea. For some source countries, migration is seen as a phenomenon that will reduce unemployment and provide foreign exchange input. On the other hand, those who migrate will lose their ties with their countries over time. In the countries they go to, their children fall into the trap of organizations or organ mafia. The European people think that the cheap labor force reaching their countries harms them economically and socially. The West, which employs as many migrants as it needs, takes migrants out of work first in times of crisis. While multiculturalism, which is the basis of European development, remains in theory, assimilation methods are desired to be developed. The policy of removing immigrants from their identities, such as the use of antiSemitism in Europe in the 1930s as a tool of German politics, is being sought. Changes in the international conjuncture directly affect Turkey's immigration policy. Russia's invasion of Afghanistan, the Iranian revolution, Saddam's activities, the process of Yugoslavia's 
disintegration and the Arab Spring has accelerated the migration to Turkey. Turkey's strategic location, the presence of sea and land transportation facilities to facilitate the transit countries has paved the way. In addition, being an economic center of attraction and the existence of laws that facilitate migration are among the main reasons affecting migration. Turkey, which also apply to asylum-seekers which is a system of EU state events in Yugoslavia, is implementing temporary protected status recognized as a recommended method for emergencies. A significant number of those who enter Turkey illegally intend to stay in the country. The increasing number of asylum seekers, the occasional difficulty in meeting the needs of non-governmental organizations, and the fact that some of those involved in illegal activities originate from asylum seekers are relatively affecting the approach to foreigners in Turkey.

As a result of the social and economic transformation caused by necessity in the globalized world, migration is a matter that the international community needs to find a common solution and should be evaluated with a supranational approach. In the media organs, events such as arrest, deportation and death are often brought to the agenda in the magazine mentality. There is a common belief that illegal immigration can be prevented by border measures. Although the borders are equipped with deep ditches, wire fences and thermal systems, illegal immigrants who risk death die every way. Migrants are open to economic and political exploitation in the countries they go to and are unable to protect their culture. It should be assumed that immigration, which is a social phenomenon, is a human-based and long-term issue that should be evaluated apart from security concerns. As in Europe, concerns about migrants in Turkey are centered on the "security and order" axis. Security measures slow down migration but cannot terminate it. There are developing countries, including Turkey, where illegal immigration has had to bear the burden. Considering that the causes of migration are economic inequality and human rights violations, it should be resolved at the source of illegal immigration through policies to be implemented in the medium and long term towards the source countries. The current situation causes poor countries to pay large prices due to refugees. Rich countries in the target position need to review their development plans for countries in the resource position. Also, asylum-seekers who want to return to their countries should be encouraged. 